\title{
Myocardial infarction in a patient with moderate haemophilia A
}

Zawał mięśnia sercowego u pacjenta z umiarkowaną hemofilią $\mathrm{A}$

\author{
Ewa Czubak, Aleksandra Serwicka, Andrzej Dziekoński, Grzegorz Fitas
}

Department of Cardiology, Hospital in Starachowice, Poland

Post Kardiol Interw 2011; 7, 1 (23): 101-104 DOI: 10.5114/pwki.2011.21198

\begin{abstract}
We report a case of patient with a moderate haemophilia A and myocardial infarction. The patient underwent a successful coronary angioplasty preceded by factor VIII administration, nevertheless the double antiplatelet therapy was complicated by gastrointestinal bleeding, which occurred after the discharge. Additionally, the article discusses the treatment strategies of acute coronary syndrome in patients with haemophilia.
\end{abstract}

Key words: haemophilia A, myocardial infarction, percutaneous coronary intervention

\section{Streszczenie}

Przedstawiamy przypadek 61-letniego mężczyzny z umiarkowaną hemofilią A i zawałem mięśnia sercowego. U pacjenta wykonano skuteczny zabieg angioplastyki wieńcowej z implantacją stentu poprzedzony substytucją czynnika VIII. Zastosowana podwójna terapia przeciwpłytkowa powikłana była krwawieniem z przewodu pokarmowego. W dalszej części pracy dokonujemy przeglądu strategii postępowania w ostrym zespole wieńcowym u pacjentów z hemofilią A.

Stowa kluczowe: hemofilia A, zawał mięśnia sercowego, angioplastyka wieńcowa

\section{Introduction}

Haemophilia A is a hereditary coagulation disorder with recessive $\mathrm{X}$-linked mode of transmission. It is caused by decreased activity of factor VIII in plasma. Before the development of specific therapies most patients with haemophilia died during childhood or in early adulthood due to bleeding complications [1]. After the introduction of treatment with factor VIII substitutes the number of deaths caused by bleeding related to haemophilia dropped and the mean survival time of the patients increased [2]. Aging of the population of patients with haemophilia caused an increase in the frequency of age-related diseases including coronary disease [3]. Below, we describe a case of a patient with moderate haemophilia A and anterior wall myocardial infarction.

\section{Case report}

A 61-year-old male, a smoker, without a history of cardiovascular diseases, was admitted to the Cardiology
Department of the Regional Hospital in the second hour of typical anginal chest pain. Medical history of the patient included haemophilia $A$, hepatitis $C$ and prior gastric resection due to duodenal ulcer. The patient was diagnosed with a moderate form of haemophilia ( $5 \%$ of factor VIII activity and no antibodies against factor VIII). During childhood the patient suffered from frequent spontaneous intra-arterial haemorrhages which in consequence led to arthropathy. Haemorrhages decreased spontaneously after 30 years of age. The patient received only one infusion of factor VIII concentrate due to tooth extraction 1.5 years before the present hospitalization. On admission he was in moderate general condition and had stenocardia. On physical examination he had pale skin and contractures of the cubital, knee and hip joints. Blood pressure was 125/90 mmHg, heart rhythm $75 \mathrm{bpm}$. There were no signs or symptoms of heart failure. ECG showed $2 \mathrm{~mm}$ high ST-segment elevation in leads $V_{2}-V_{4}$. Echocardiography performed on the day of admission demonstrated apical hypokinesis with

Corresponding author/Adres do korespondencji:

Aleksandra Serwicka MD, Department of Cardiology, Hospital in Starachowice, ul. Radomska 70, 27-200 Starachowice, tel.: +48 4127396 10, fax: +48 4127390 67, e-mail: aserwicka@poczta.onet.pl

Praca wpłynęła 24.11.2010, przyjęta do druku 20.02.2011. 
ejection fraction of $50 \%$. Laboratory examinations on admission showed microcytic anaemia (Hgb $8.6 \mathrm{~g} / \mathrm{dl}$, Hct $31.1 \%$, RBC $4.81 \times 10^{6} / \mu \mathrm{l}$, MCV $64.7 \mathrm{fl}$ ), prolonged APTT of $60.7 \mathrm{sec}$, hypercholesterolaemia (total cholesterol 209 mg/dl, LDL 147.8 mg/dl, triglycerides 80 mg/dl). Due to anaemia the patient underwent surgical consultation, but no signs of active gastrointestinal bleeding were found. The patient refused coronary angiography and therefore conservative treatment was started. He received $300 \mathrm{mg}$ of aspirin followed by a maintenance dose of $75 \mathrm{mg} / \mathrm{d}$ and $600 \mathrm{mg}$ of clopidogrel followed by a maintenance dose of $75 \mathrm{mg} / \mathrm{d}$, metoprolol $2 \times 25 \mathrm{mg} / \mathrm{d}$, atorvastatin $40 \mathrm{mg} / \mathrm{d}$ and an intravenous infusion of nitroglycerine. Because of anaemia and persistent chest pain the patient received 2 units of red blood cells. Resting chest pain resolved after introduction of treatment. ECG performed during the following days of hospitalization demonstrated evolution of anterior wall myocardial infarction. Laboratory tests showed typical rise of biochemical markers of myocardial necrosis (CK-MB max. $40 \mathrm{U} / \mathrm{l}$, troponin $\mathrm{T} \max .0 .47 \mu \mathrm{g} / \mathrm{l}$ ). On the $4^{\text {th }}$ and $5^{\text {th }}$ day of hospitalization the patient suffered from recurrent resting chest pains. After obtaining informed written consent the patient was prepared for invasive treatment. The patients was consulted in the Institute of Haematology and Transfusiology in Warsaw to determine the requirement for factor VIII to obtain its 80 $100 \%$ activity in plasma. It was defined as $50 \mathrm{U} / \mathrm{kg}$ of body mass and therefore $3500 \mathrm{U}$ of factor VIII was infused before coronary angiography performed using a transradial

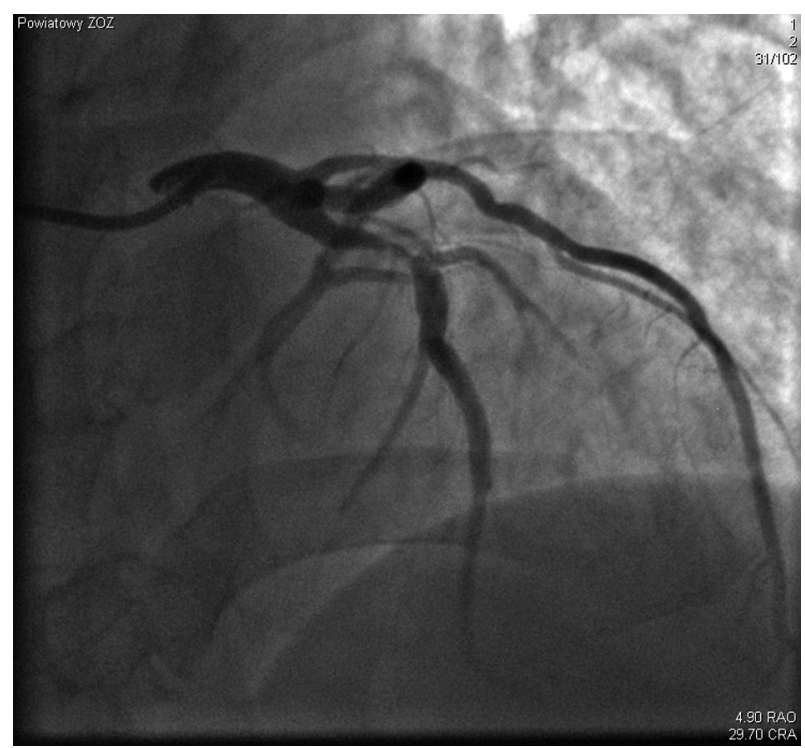

Fig. 1. Coronary angiogram before $\mathrm{PCl}-90 \%$ stenosis in proximal segment of LAD

Ryc. 1. Koronarografia u pacjenta przed zabiegiem $\mathrm{PCl}$-90-procentowe zwężenie w proksymalnym segmencie gatęzi międzykomorowej przedniej obejmujące ostium gatęzi diagonalnej approach. Angiography showed $90 \%$ stenosis of the proximal left anterior descending artery (LAD) segment including the ostium of a diagonal branch with TIMI 1 flow (fig. 1) and recessive right coronary artery with long stenosis of up to $90 \%$ in proximal and mid artery segments. Successful percutaneous coronary intervention $(\mathrm{PCI})$ with bare metal stent implantation to the LAD was performed (fig. 2). The patient received 5000 IU of unfractionated heparin. During the remaining hospitalization the patient was given further doses of factor VIII as suggested by the haematologist: $40 \mathrm{U} / \mathrm{kg}$ of body mass 12 hours after $\mathrm{PCl}$ and on days 2-4, followed by $30 \mathrm{U} / \mathrm{kg}$ of body mass on days 5-7. Due to persistent anaemia the patient underwent gastroscopy which did not disclose any site of bleeding. The patient refused colonoscopy. There were no recurrences of chest pain or any bleeding complications until the end of hospitalization. The patient was discharged home on aspirin $75 \mathrm{mg} / \mathrm{d}$, clopidogrel $75 \mathrm{mg} / \mathrm{d}$, metoprolol prolonged-release $50 \mathrm{mg} / \mathrm{d}$, ramipril $2.5 \mathrm{mg} / \mathrm{d}$, atorvastatin $40 \mathrm{mg} / \mathrm{d}$ and pantoprazole $2 \times 20 \mathrm{mg}$. On telephone contact 2 months after discharge the patient reported 2 episodes of massive gastrointestinal bleeding (on days 39 and 61 after myocardial infarction). During the first hospitalization he was diagnosed with erosive gastritis, but subsequent hospitalization did not disclose any site of bleeding. After cardiological consultation aspirin was discontinued. At present the patient is on chronic therapy with clopidogrel and factor VIII and is scheduled to undergo further gastrointestinal examinations.

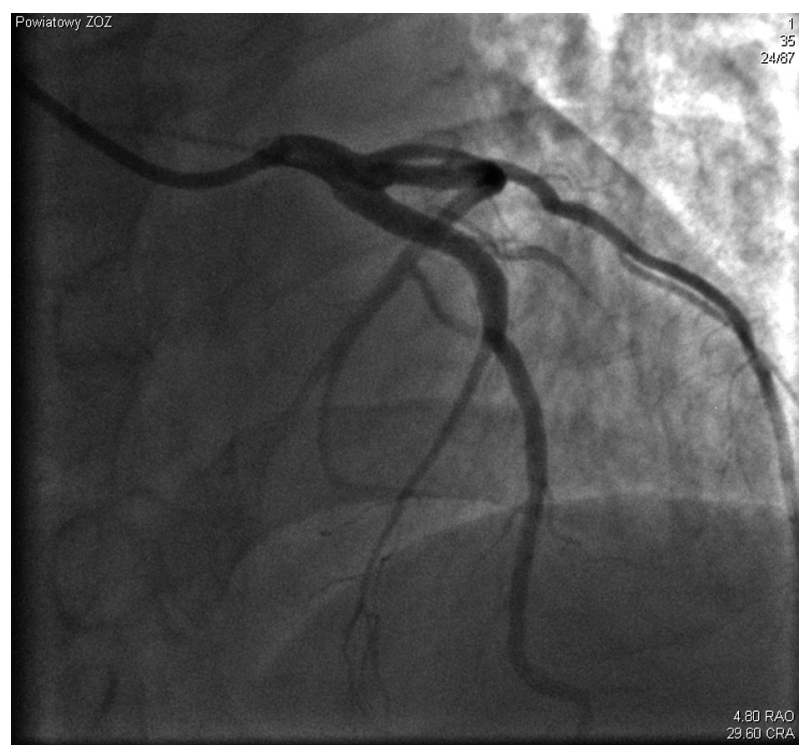

Fig. 2. Coronary angiogram after stent implantation Ryc. 2. Obraz angiograficzny po zabiegu skutecznej angioplastyki 


\section{Discussion}

The frequency of cardiovascular incidents and mortality related to coronary artery disease is lower in patients with haemophilia in comparison to the general population [2, 3]. It was demonstrated that reduction of mortality is not related to lower prevalence of typical cardiovascular risk factors [4]. Lower mortality caused by coronary artery disease in patients with haemophilia is probably caused by lower activity of factor VIII [5]. Furthermore, it seems that infusion of factor VIII substitutes may cancel the protective effect of haemophilia on onset of coronary disease. Most cases of acute coronary syndromes (ACS) described in the literature occurred after substitution of factor VIII [6-8]. Low activity of factor VIII probably protects against thrombus formation in coronary arteries, but it does not protect against the development of atherosclerotic plaques [9].

At present there are no uniform guidelines on the treatment of patients with ACS and haemophilia. Management is based on the general guidelines of the European Society of Cardiology (ESC) on ACS and on a few cases of treatment of such patients described in the literature [10]. The preferred mode of treatment in ACS is to perform PCI [10], which in patients with haemophilia is related to higher risk of bleeding complications. To reduce the risk of local bleeding it is recommended to use transradial access [11], although there have been cases of uncomplicated $\mathrm{PCl}$ procedures performed using a transfemoral approach $[12,13]$. $\mathrm{PCl}$ in patients with haemophilia should be performed under factor VIII concentrate protection. There are no uniform guidelines for percutaneous procedures and therefore it is accepted that the activity of factor VIII during the procedure should be similar to that recommended for surgical procedures, i.e. $80-100 \%[11,14,15]$. Increase of bleeding risk is also related to the obligatory administration of antithrombotic drugs during $\mathrm{PCl}$. In that case we used unfractionated heparin. Bivalirudin, a direct thrombin inhibitor, is an alternative drug, especially in patients with increased risk of bleeding complications $[10,15,16]$. It does not require APTT monitoring and causes fewer bleeding complications [17]. There are no described bleeding complications during $\mathrm{PCl}$ in patients with haemophilia performed on heparin or bivalirudin in the literature. A major concern in patients with myocardial infarction and haemophilia is related to the need for dual antiplatelet therapy (aspirin and clopidogrel). Among similar cases (treated with $\mathrm{PCl}$ ) described in the literature, there were patients who did not receive antiplatelet drugs [18], some who received aspirin or clopidogrel [7, 8], but most of them received typical dual antiplatelet therapy $[6,12,13,15,16]$. Some patients on dual antiplatelet therapy experienced non-lifethreatening bleeding complications (bleeding from the gums, ecchymoses, purpura, joint haemorrhages), which required discontinuation of one of the drugs $[6,12,16]$. The described patient suffered from massive gastrointestinal bleeding which required discontinuation of aspirin, but not clopidogrel. This case illustrates major difficulties in management of patients with ACS and haemophilia A caused by the delicate balance between antithrombotic and antiplatelet treatment and prevention of bleeding complications in the course of congenital coagulation disorders.

\section{References}

1. Mauser-Bunschoten EP, Fransen Van De Putte DE, Schutgens RE. Co-morbidity in the ageing haemophilia: the down side of increased life expectancy. Haemophilia 2009; 15: 853-863.

2. Darby SC, Kan SW, Spooner RJ, et al. Mortality rates, life expectancy, and causes of death in people with hemophilia A or $B$ in the United Kingdom who were not infected with HIV. Blood 2007; 110: 815-825.

3. Kulkarni R, Soucie JM, Evatt BL. Prevalence and risk factors for heart disease among males with hemophilia. Am J Hematol 2005; 79: 36-42.

4. Rosendaal FR, Briët E, Stibbe J, et al. Haemophilia protects against ischaemic heart disease: a study of risk factors. Br J Haematol 1990; 75: 525-530.

5. Sramek A, Kriek M, Rosendaal FR. Decreased mortality of ischaemic heart disease among carriers of haemophilia. Lancet 2003; 362: 351-354.

6. Günaldi M, Helvaci A, Yildirim ND, et al. Acute myocardial infarction in a patient with hemophilia $A$ and factor $V$ Leiden mutation. Cardiol J 2009; 16: 458-461.

7. Kerkhoffs JL, Atsma DE, Oemrawsingh PV, et al. Acute myocardial infarction during substitution with recombinant factor VIII concentrate in a patient with mild haemophilia A. J Thromb Haemost 2004; 92: 425-426.

8. Girolami A, Ruzzon E, Fabris F, et al. Myocardial infarction and other arterial occlusions in hemophilia a patients. A cardiological evaluation of all 42 cases reported in the literature. Acta Haematol 2006; 116: 120-125.

9. Foley CJ, Nichols L, Jeong K, et al. Coronary atherosclerosis and cardiovascular mortality in hemophilia. J Thromb Haemost 2010; 8: 208-211.

10. The Task Force on the management of ST-segment elevation acute myocardial infarction of the European Society of Cardiology. Eur Heart J 2008; 29: 2909-2945.

11. Dziewierz A, Dudek D. Jak postępować u chorego z ostrym zespołem wieńcowym, gdy wspótistnieją zaburzenia hematologiczne - punkt widzenia kardiologa interwencyjnego. Post Kardiol Interw 2008; 4: 164-172.

12. Smolka G, Kulach A, Dabek J, et al. Percutaneous coronary intervention with stent implantation in haemophilic A patient with unstable angina. Haemophilia 2007; 13: 428-431.

13. Wójcik D, Rekosz J, Woźniak J, Leszczyński L. Zawał serca u chorego z hemofilią typu A. Kardiol Pol 2003; 59: 417-420.

14. Guidelines for the management of hemophilia. CWorld Federation of Hemophilia, 2005, Montréal, Canada at www.wfh.org

15. Arora UK, Dhir M, Cintron G, et al. Successful multi-vessel percutaneous coronary intervention with bivalirudin in a patient with severe hemophilia A: a case report and review of literature. J Invasive Cardiol 2004; 16: 330-332. 
16. Quintero D, Biria M, Meyers DG. Percutaneous coronary intervention in a patient with acute ST-elevation myocardial infarction and hemophilia A. J Invasive Cardiol 2008; 20: 240-241.

17. Stone GW, Witzenbichler B, Guagliumi G, et al. for the HORIZONSAMI Trial Investigators. Bivalirudin during Primary $\mathrm{PCl}$ in Acute Myocardial Infarction. N Engl J Med 2008; 358: 2218-2230.
18. Ergelen M, Osmonov D, Gunaydin ZY, et al. Acute inferior myocardial infarction in a patient with severe haemophilia A disease. Ann Hematol 2009; 88: 711-712. 